\title{
STATE CHARACTERISTICS OF THE PROBLEM OF ORAL CAVITY ENVIRONMENTAL SYSTEM
}

DOI: 10.36740/WLek202005137

\author{
Oksana V. Dobrovolska ${ }^{1}$, Nataliia V. Hasiuk², Oksana V. Klytynska ${ }^{3}$, Marta S. Zaliznyak², Iryna V. Antonyshyn², \\ Khrystyna V. Pogoretska², Ludmila A. Patskan² \\ 'UKRAINIAN MEDICAL STOMATOLOGICAL ACADEMY, POLTAVA, UKRAINE \\ ${ }^{2}$ TERNOPIL STATE MEDICAL UNIVERSITY, TERNOPIL, UKRAINE \\ 3UZHHOROD NATIONAL UNIVERSITY, UZHHOROD, UKRAINE
}

\begin{abstract}
The aim: Analysis of literary sources with the study of modern views on the problem of the immune status of the oral mucosa.

Materials and methods: The review and analysis of scientific and medical literature for the years 2013-2019, based on Scopus databases, Web of Science, Med Line, The Cochrane Library, EMBASE, Global Health, CyberLeninka, RIC.

Conclusions: Bacterial wall antigens are able to affect the local immune response of the oral mucosa. In particular, suppression of lymphocytes and macrophages proliferation, alteration of adhesion molecules expression and homing of the immune system cells to the inflammation site, inhibition of cytokine secretion by contact of the immune system cells with gram-positive bacteria is revealed.

Therefore, studying the changes in the differentiation of the oral mucosa epithelium and periodontal tissues under the influence of environmental factors is of relevance. The conception of the oral cavity as a complex ecological system has not only theoretical but also practical value. Summarizing the data, we can say that at the current stage of science development the interaction of all structures should be considered, focusing on epitheliocytes of the oral mucosa, as a closing chain, which initiates changes that can affect the condition of the oral cavity and the results of pathological processes treatment of the oral cavity mucous membrane and periodontal tissues.
\end{abstract}

KEY WORDS: oral cavity, epithelial cells, inflammatory process, periodontal tissues

Wiad Lek. 2020;73(5):1037-1040

\section{INTRODUCTION}

There is a multicomponent system of protection against the negative impact of the environment in the oral cavity, the first line of which is the mucous membrane, including epithelial cells, cells of the immune system and their cytokines [1]. Epithelial cells are commonly regarded as an integral part of the immune tissue associated with the mucous membranes [2].

The recognition of bacterial structures by epitheliocytes is controlled by Tol-like TLR-4, TLR-2, and Nod-like receptors NOD-1, NOD-2, PAR, but is not restricted to genes of the major histocompatibility complex, which allows this type of protection attributed to natural immunity $[3,4]$.

Today it is proved that epithelial cells have been shown to be hypoactive against pathogenic bacteria, because the expression level of TLR receptors relative to the apical surface of the cell is low, whereas at the time of invasion bacteria can activate the receptors located intracellularly or at the basal pole [5].

Recent works have shown [6] that saprophytes also initiate the inflammatory process of the oral mucosa and periodontal tissues. The epithelial cells do not phagocytize the bacteria that interact with the adhesion receptors, but they regulate the dynamics of the active cytoskeleton, allowing the bacteria to form pinocytotic vesicles and thus to invaginate into a cell.
In response to bacterial peptidoglycans, the oral cavity epitheliocytes synthesize a number of cytokines, including antimicrobial peptides, which are part of natural immunity [7].

The epithelium regulates the immune response to the microbial factors of the oral cavity. Bacterial lipopolysaccharides and acids stimulate the secretion by the epithelium cells of proinflammatory cytokines, including IL-1b, IL-8, TNF- $\alpha$, which initiate the inflammatory process in the periodontium and oral mucosa. Inflammation of the oral mucosa is accompanied with increased expression of keratinocyte growth factor receptors in the basal and parabasal layers of the epithelium of periodontal pockets and inflamed mucosa [8].

\section{THE AIM}

The aim was the analysis of literary sources with the study of modern views on the problem of the immune status of the oral mucosa.

\section{MATERIALS AND METHODS}

The review and analysis of scientific and medical literature for the years 2013-2019, based on Scopus databases, Web 
of Science, MEDLINE, The Cochrane Library, EMBASE, Global Health, CyberLeninka, RIC.

\section{REVIEW AND DISCUSSION}

Transforming growth factor is released by epitheliocytes, thus inhibiting the induced by bacteria activation of the transcription factor NF- $\kappa B$, its interaction with the promoter of the gene IL- 6 , which causes modulation of histone-acetylase and alteration of gene expression, and also reduces activation of the inflammatory process in tissues [9].

In the formation of innate immunity, a significant role belongs to the peptide calprotectin, which is synthesized by the epitheliocytes of the gums, its synthesis is regulated by transforming growth factor [10]. Epitheliocytes synthesize cytokeratins, involucrin, filagrin, the expression of which is increased in inflammatory diseases of the oral mucosa and periodontal tissues.

The epithelium provides migration of the immune system cells into the oral cavity. Saliva, as part of the oral cavity environmental system, is characterized by certain physical and chemical properties, such as $\mathrm{pH}$, buffer capacity, salivation rate. Saliva includes secretions of parotid, sublingual and submandibular salivary glands, which differ by quantitative protein content, cytokine composition and enzyme activity [11].

The highest concentration of protein is contained in the secretion of the parotid glands. Saliva contains a number of biologically active substances, enzymes and regulatory peptides such as IL-1, IL-6, IL-8, epithelial growth factors, nerves, platelet-synthesized growth factor, major fibroblast growth factor, and other cytokines, the concentration of which increases with inflammatory diseases of the oral cavity and during proliferative processes.

These biologically active substances influence the mucous membrane of the oral cavity and periodontal tissue. The content of cytokines in saliva is determined by the activity of macrophages and monocytes of mucous and gum fluid. Baseline levels of prostaglandin E2 and other prostaglandins in saliva also play a role in the pathogenesis of periodontitis. Healthy individuals have prostaglandin E2 which binds to R-E2 and R-E4 receptors and that reduces the synthesis of matrix metalloproteinases, influencing extracellular matrix remodeling. Patients with periodontitis have prostaglandin E2 which binds to the E1 receptor, that increases IL-1b-dependent synthesis of matrix metalloproteinases and tissue proteolysis. The proteolytic system of saliva regulates the lysis and colonization activity of the bacteria in the oral cavity [12].

In this case, there is a feedback system, when the microflora of the oral cavity can cause hyposalivation [13].

The lymphoid tissue associated with the mucous membranes of the oral cavity is divided into inductive and effector [14].

The inductive zone includes tonsils, lymphoid follicles, lymphatic vessels that provide migration of the immune system cells to the antigens of the mucous membrane. The effector zone is represented by regional lymph nodes, mucous membrane and epithelial cells of the oral cavity.
Today, immunity is divided into adaptive and innate. Cells that provide innate immunity are phylogenetically earlier [15].

Their antigen recognition is not genetically restricted, so the response to foreign structures occurs immediately after contact [16].

Cells of adaptive immunity are phylogenetically farther and specialized; their functional activity depends on the presence on the plasma membrane of the major histocompatibility complex gene products. The intensity of the immune response is determined by the genes of the histocompatibility complex and varies due to the influence of some factors. There are cellular and humoral types of immune response, as well as non-specific response of the organism. These types of immune response are the links of the single mechanism for maintaining the body homeostasis provided by the immune system [17].

The oral mucosa contains a large number of plasma cells, $90 \%$ of which are IgA-producing. One of the mechanisms of providing protective action under the influence of microbial factors is the synthesis of secretory IgA, which limits the contact between saprophytic microorganisms and cells of the oral cavity epithelium, and prevents inflammation. The environmental system of the oral cavity balances between immune response and tolerance to the antigens. The nature of the immune response is determined by quantitative characteristics, that is, the intensity of action of one factor or another [18].

The intense microbial contamination of the oral cavity causes the presence of high proinflammatory potential in the gums. Bacteria regulate the migration processes of the immune system cells to the foci of inflammation and the suppressive action of lymphocytes, which promotes the active colonization of bacteria in conditions of immune system active action. Bacterial wall antigens are able to affect the local immune response of the oral mucosa. In particular, suppression of lymphocytes and macrophages proliferation, alteration of adhesion molecules expression and homing of the immune system cells to the inflammation site, inhibition of cytokine secretion by contact of the immune system cells with gram-positive bacteria is revealed [19].

The worldwide prevalence of smoking is about $65 \%$ for men, about $30 \%$ for women and $50 \%$ for boys and girls of high school. It should be noted that prevalence rates have increased 2-3 times over the last 5-10 years [20].

Smoking is one of the most widespread harmful habits, which leads to the impact on the oral mucosa tissues and periodontal tissues of substances containing about 4 thousand active compounds that can provoke specific changes of the oral mucosa, periodontium and hard tooth tissues [21].

The main effect of smoking is attributed to the activation of bacterial aggression and increased microbial plaque, soft plaque and calculus formation [22].

In national and foreign literature, there are isolated reports on the effects of tobacco smoke on microcirculation disorders [23], but there are only few researches, 
which makes it possible to argue that the mechanisms of smoke influence on the development of pathological processes in the oral mucosa and periodontal tissues are not well-studied.

The tendency for a rapid increase in the percentage of smokers among young people of both sexes poses new challenges for odontologists and specialists in pathology of the oral mucosa. The prevalence of periodontal disease, according to most observations, is higher in smokers and smokers are prevalent among patients with inflammatory periodontal disease [24].

However, with a sufficiently large amount of research on the effects of smoking, there is no comprehensive work available in foreign literature that would allow to from a complete picture on the effect of smoking on the oral mucosa and periodontal tissues. In national literature, such data is almost never found [25].

\section{CONCLUSIONS}

Therefore, studying the changes in the differentiation of the oral mucosa epithelium and periodontal tissues under the influence of environmental factors is of relevance. The conception of the oral cavity as a complex ecological system has not only theoretical but also practical value. Summarizing the data, we can say that at the current stage of science development the interaction of all structures should be considered, focusing on epitheliocytes of the oral mucosa, as a closing chain, which initiates changes that can affect the condition of the oral cavity and the results of pathological processes treatment of the oral cavity mucous membrane and periodontal tissues.

\section{REFERENCES}

1. HasiukN.V. Tsytolohichni itsytohenetychni osoblyvosti slyzovoi obolonky porozhenyny rota v noryi ta pry zapalnomu protsesi [Cytological and cytogenetic features of oral mucosa in human normal and inflammation]. Kyiv: A. Bohomolets National Medical University; 2015; 122-134. (UA).

2. Bykov V.L. Hystolohyia y embryolohyia orhanov polosty rta cheloveka [Histology and embryonic development of the human oral cavity: a training manual]. GEOTAR-Media; 2014; 342-357. (Ru).

3. Schnare M., Rollinghoff M., Qureshi S. Toll-like receptors: sentinels of host defence against bacterial infection. J. Allergy Immunol. 2006; 139 (76): 75-85.

4. Schwartz J.L. Oral cytology assessment by flow cytometry of DNA adducts, aneuploidy, proliferation and apoptosis shows differences between smokers and non-smokers. Oral Oncol. 2003;39 (8): 842-854.

5. Bradshaw D.D., Bradshaw K., Homer D. Metabolic cooperation in oral microbial communities during growth on mucin. Microbiology. 2004; 140 (12): 407-412.

6. Malko N.V., Hasiuk P.A., Ivanchyshyn V.V., Hasiuk N.V. Changes in biochemical parameters of blood serum and gingival homogenates with experimental gingivitis. The world of medicine and biology. 2017; 4 (62): 149-152.

7. Hasiuk P., Hasiuk N., Kindiy D., Ivanchyshyn V. et al. Characteristics of cellular composition of periodontal pockets. Interventional Medicine and Applied Science. 2016. 8(4): 172-177.
8. Furdychko A.I., Hasiuk P.A., Ivanchyshyn V.V., Hasiuk NV Clinicallaboratory justification of dependence of periodontal inflammatory diseases on the condition of hepatobiliary system. World of medicine and biology. 2018; 1 (63): 87-89.

9. Hasiuk N.V. Rol polimorfnykh variantiv yadernoho faktora transkryptsii vprohnozuvanni rozvytku heneralizovanoho parodontytu [Description of the polymorphic variants of nuclear transcription factor NF-kB1 as predictors of generalized periodontitis development]. Ukrainian Scientific Medical Youth Journal. 2016; 1 (93): 105-107. (UA).

10. Hasiuk N.V., Levandovsky R.A., Borodach V.0., Klytynska 0. et al. Morfological substantion of criteria of prediction of clinical cours of generalized periodontitis. World of medicine and biology. 2018; 3 (65): 46-50.

11. Kaydashev I.P. Narysy imunobiolohii slyzovoi obolonky rotovoi porozhnyny: monohrafiia [Essays on the immunobiology of the oral mucosa: a monograph]. Poltava; 2008; 144-267. (UA).

12. Vernal R., Chaparro A., Graumann R. Levels of cytokine receptor activator of nuclear factor kappa $B$ ligand in gingival crevicular fluid in untreated chronic periodontitis patients. J. Periodontol. 2004; 75 (12): $1586-91$.

13. Klitynska 0., Gasyuk N., Kostenko Ye., Gurando V. Statistical model of caries formation and progression in children of preschool and early school age domiciled in biogeochemical deficiency of fluorine and iodine. Journal of Stomatology. 2017; 70(6): 674-678.

14. Klytynska 0., Vasko A., Borodach V., Hasiuk N. et al. Clinical and Laboratory Grounds for the Rational Selection of Filling Material for Restoration of Temporary teeth. Pesquisa Brasileira em Odontopediatria e Clinica Integrada. 2018; 18(1): 3949.

15. Kuramitsu H.K., Miyalcawa H. Cellular responses to oral pathogens. Ann. Periodontol. 2002; 7 (1): 90-91.

16. Hasiuk N.V., Yeroshenko G.A., Maystruk P.O. Features of the cell complex of the mortal shell of the rope cavity on the field of tolerancy. World of medicine and biology. 2018; 4 (66): 157-160.

17. Darveau R.P., Pham T.T., Lemley K. Porphyromonas gingivalis Lipopolysaccharide Contains Multiple Lipid A Species That Functionally Interact with Both Toll-Like Receptors 2 and 4. Infect and immun.2004; 72: $504-551$.

18. Michael H., Wojciech P. Histology: a text and atlas: with correlated cell and molecular biology. Lippincott Williams \& Wilkins. 2011; 646-672.

19. Solan N.J., Miyoshi H., Carmona E.M. Rel B cellular regulation and transcriptional activity are regulated by p100. J. Biol. Chem. 2002; 277 (2): 1405-1418.

20. Vartonyan F.Ye. The fight against smoking in the world: strategies and trends. Narcology. 2003; 4:2-4.

21. Lova R.M. Morphologic changes in the microcirculation induced by chronic smoking habit: a videocapillaroscopic study on the human labial mucosa. Am. Heart. J. 2002; 143 (4): 658-662.

22. Mirbod S.M., Ahing S.I., Tobacco-associated lesions of the oral cavity: Part I. Nonmalignant lesions. Can. Dent. Assoc. 2000; 66 (5): 58-62.

23. Hujoel P.P., Drangsholt M., Spiekerman C. Periodontitis-systemic disease associations in the presence of smoking causal or coincidental. Periodontol. 2002; 67 (7): 51-60.

24. Sethi P., Shah P.M. Oral exfoliative cytology of smokers at discrete clinical stages using AgNOR staining. Mutat. Res. 2004; 11 (4): 15-21.

25. Ulevitch R.J. Therapeutics targeting the innate immune system. Nat. Rev. Immunol. 2004; 12 (4): 512-520.

The article was made within the framework of the research work of the Department of Therapeutic Dentistry of Ter- 
nopil National Medical University «Development of new individualized approaches to the diagnosis, treatment and prevention of dental diseases in patients with primary and secondary lesions of oral tissues based on the study of their pathogenetic mechanisms», №0117U003024.

\section{ORCID and contributionship:}

Oksana V. Dobrovolska - 0000-0002-7786-1349 ${ }^{A}$

Nataliia V. Hasiuk - 0000-0002-6798-9090 ${ }^{B}$

Oksana V. Klytynska - 0000-0001-9969-2833 ${ }^{F}$

Marta S. Zaliznyak - 0000-0002-9980-4556 ${ }^{B}$

Iryna V. Antonyshyn - 0000-0002-1252-9177 ${ }^{D}$

Khrystyna V. Pogoretska - 0000-0002-6505-6086 ${ }^{E}$

Ludmila A. Patskan - 0000-0003-2584-5942 ${ }^{F}$

\section{Conflict of interest:}

The Authors declare no conflict of interest.

\section{CORRESPONDING AUTHOR}

\section{Nataliia V. Hasiuk}

Ternopil State Medical University

Maidan Voli 1, Ternopil, 46001, Ukraine

tel: +38(03522)5-39-98.

e-mail: gasyuk.natasha@gmail.com

Received: 28.01 .2020

Accepted: 01.04 .2020

A - Work concept and design, B - Data collection and analysis, C - Responsibility for statistical analysis,

D-Writing the article, $\mathbf{E}$-Critical review, $\mathbf{F}$ - Final approval of the article 